DOI https://doi.org/10.36059/978-966-397-116-2/194-219

\title{
NORMATIVE AND LEGAL FRAMEWORK FOR ANTI-ORGANIZED CRIME IN UKRAINE
}

\section{Miniailo N. Ye.}

\section{INTRODUCTION}

Organized crime is now a significant factor in increasing social tension and destabilizing social relations, impeding the recovery of the economy, the ordering of the consumer market, and the deformation of new forms of economic entrepreneurial relations. The processes of aggregation of economic and general criminal crime, leaders of criminal groups with corrupt officials of government and administration, and law enforcement agencies are intensifying.

Organized crime is currently regarded as a real threat to national security in connection with the inclusive nature of its impact on various spheres of public life. In recent years, officially recognizing the existence of organized crime in Ukraine, which poses a threat to the national security of the state, much has been done in terms of disclosing its essence, content, etc.

Attracting representatives of organized crime to criminal responsibility for acts recognized as a crime is a clear requirement of the present. However, not always a certain crime refers to its manifestations, although in its essence is such. The current system of accounting for detected crimes also does not foresee their distribution on this basis. Accordingly, modern criminological research and conclusions can not always be confirmed by existing statistical data. Official statistics do not allow to immediately trace the spheres of life of Ukrainian society, in which organized crime operates.

Organized crime is a complex set of criminal offenses, such as: the provision of illegal goods and services, carefully planned and coordinated fraudulent operations, theft, extortion committed by organized crime groups. The term «organized crime» is also used to identify individuals involved in the activities of groups, organized crime forms. Organized crime is a special social danger, a «peak of crime». The basis for distinguishing this type of crime, scientists consider the nature and degree 
of interaction of criminals in the commission of illegal activities. It takes place on the basis of the unification of individuals, the delineation of criminal roles between them, the hierarchy of the system of relationships.

The tendency of recent years shows the growing interest of leaders of criminal groups to actively be included in legal commercial structures. Practice shows that they legalize their activities through the creation of various associations, joint ventures, intermediary organizations and cooperatives. The state's response to such activities is based on a defined strategy and according to developed state programs.

Modern dictionaries give this term «strategy» a broader meaning: the art of leadership of social processes, political struggle. In legal literature, this term refers to the art of combating crime and individual crimes, carried out on the basis of a general concept, the definition of goals and means of their achievement, the implementation of various measures.

According to the Law of Ukraine «On National Security of Ukraine» state policy in the areas of national security and defense is aimed at the protection of: a person and a citizen - their lives and dignity, constitutional rights and freedoms, safe living conditions; society - its democratic values, prosperity and conditions for sustainable development; the state - its constitutional order, sovereignty, territorial integrity and inviolability; territory, the environment - from emergency situations.

Among the priority directions of ensuring the national security of Ukraine the state also defined the sphere of counteraction of crime, in particular organized crime, and identified the main authorized entities. Coordination in the areas of national security and defense is carried out by the National Security and Defense Council of Ukraine. The Ministry of Internal Affairs of Ukraine is the central executive body that ensures the formation and implementation of state policy in the areas of ensuring the protection of human rights and freedoms, the interests of society and the state, combating crime, maintaining public safety and law and order.

The National Police of Ukraine is a central executive body that provides public security and order, protection of human rights and freedoms, interests of society and the state, counteraction to crime, and also provides services defined by law for persons who, for personal, economic, social reasons or as a result of Emergency situations require such assistance. 
The National Guard of Ukraine is a military formation with law enforcement functions designed to carry out tasks for the protection and protection of life, rights, freedoms and legitimate interests of citizens, society and the state from criminal and other illegal encroachments, public order and public security, as well as in interaction with other bodies - on ensuring the state security and protection of the state border of Ukraine, the cessation of terrorist activities, the activities of illegal paramilitary or armed formations, the body called criminal groups and organizations.

The Security Service of Ukraine is a state body of special purpose with law enforcement functions that provides state security, with the strict observance of human and civil rights and freedoms:

1) counteracting reconnaissance and subversion activities against Ukraine;

2) the fight against terrorism;

3) counter-intelligence protection of state sovereignty, constitutional order and territorial integrity, defense and scientific and technical potential, cybersecurity, economic and informational security of the state, objects of critical infrastructure;

4) protection of state secrets.

The National Security Strategy of Ukraine is a document that identifies the actual threats to the national security of Ukraine and the corresponding goals, tasks, mechanisms of protection of Ukraine's national interests and forms the basis for planning and implementation of state policy in the field of national security.

\section{The concept and types of organized criminal groups}

Organized forms of crime began to appear in Ukraine at the beginning of the 20th century, although in fact, before that separate associations of criminals could legitimately be attributed to expressions of organized crime in the modern sense of this phenomenon. In large industrial as well as seaside towns, communities of criminals were formed that were stable, distributed among themselves the spheres of influence and committed active resistance to the activities of state authorities aimed at their elimination.

Since the mid-1970s, at the UN level and later in the Council of Europe a number of international legal acts were adopted to formulate strategic principles for combating organized crime. The most important of 
these are the UN Convention against Transnational Organized Crime of 15 November 2000 and its additional protocols: the Protocol to Prevent, Suppress and Punish Trafficking in Persons, Especially Women and Children; Protocol against the smuggling of migrants by land, sea and air; Convention on Laundering, Search, Seizure and Confiscation of the Proceeds from Crime, 8 November 1990, Council of Europe Convention on Laundering, Search, Seizure and Confiscation of the Proceeds from Crime and on Financing Terrorism of 16 May 2005, European Union Strategy for the New Millennium «Prevention and Control of Organized Crime»; Framework Decision of the Council of the European Union on combating fraud and counterfeiting of non-cash means of payment, dated May 28, 2001, Framework Decision of the Council of the EU of June 13, 2002 «On the European Arrest Warrant and the Transfers of Persons between Member States» and others. Appropriate congresses, seminars on crime prevention and the treatment of offenders were held, in which issues of activation of counteraction to organized crime were raised. Such events were held in Havana (1990), Suzdal (October 1991), Palermo (2000).

A characteristic feature of international treaties in the field of counteraction to organized crime is a fairly wide range of States parties. For example, 168 states have joined the United Nations Convention on Narcotic Drugs, the OOEN Convention on Combating Illicit Traffic in Narcotic Drugs and Psychotropic Substances has exceeded 158. Ukraine has also concluded dozens of interstate, bilateral treaties on legal aid in criminal matters.

In order to successfully fight organized crime joint efforts are needed to counteract criminal gangs across the European space, joint mobilization of law enforcement and judicial authorities, balanced implementation of measures and an integrated strategy that sets priorities and clear goals for the implementation of relevant action plans.

In the aforementioned international legal documents it is recognized as necessary:

- actively engage in intergovernmental cooperation in the field of counteraction to organized crime, exchange of information between law enforcement agencies on the activities of organized criminal groups;

- establish operational-technical cooperation in various spheres of counteraction to organized crime; 
- expand advisory services in order to exchange experience and new achievements in the fight against organized crime;

- improve customs, passport and transport control at the crossing of the border and the implementation of international supplies of goods;

- create data banks for participants of transnational organized crime;

- involve financial institutions in the implementation of national, regional and international programs for the prevention and counteraction of organized crime;

- provide mutual assistance in the field of criminal justice, extradition and extradition;

- constantly carry out measures aimed at combating money laundering, smuggling, trafficking in human beings, international terrorism, piracy, environmental crimes, etc.;

- intensify activities to detect suspicious banking transactions involving the transfer of money abroad;

- take effective measures and adopt appropriate laws aimed at resolute counteraction to corruption, which promotes the activities of organized criminal groups;

- develop and improve specific training programs for law enforcement personnel, and apply other mechanisms of international cooperation in combating organized crime.

The main objective of international cooperation is to ensure that counteraction to organized crime is adequately secured by the activities of state institutions and coordinated at the interstate level.

In the first years of the existence of the Soviet state, an integral part of which Ukraine was over 70 years, the negative tendencies of the development of organized forms of crime deepened. This period is characterized by economic and social devastation, caused by exhausting first world and civil wars, revolutionary unrest. The main, direct preconditions for rallying the criminal world then became three circumstances: 1) the attempts of the state to forcibly eliminate market relations in the economy; 2) collapse of the state apparatus and the lawenforcement system; 3) the spread of persistent forms of selfish-violent crime.

In subsequent periods of the development of Ukraine organized crime gradually became more and more organized in nature. There was a specific criminal subculture. In the criminal environment there were 
leaders, organizers, «criminal authorities», «law enforcement thieves» who propagated and disseminated the idea of unification of the criminal environment.

These processes became particularly intense due to the transition of Ukraine to market relations. The activities of organized criminal groups have increasingly penetrated the field of legal economic activity

Organized criminal gangs have not become a part of the scope of group and recidivism, gang formations. In essence, it has become a new qualitative phenomenon, characterized by the merger of various types of crimes into a single activity. Separate socially dangerous acts in this case - only certain operations of more complex criminal activity. There is a system of multilevel, persistent criminal ties that lead to a concentration of crime. The basis of organized crime lies in the mercenary motivation of behavior not only of an individual, but of entire social groups, which is aimed primarily at enrichment, violation of the generally accepted principles of distribution of national income. Various unlawful means carried out the privatization of state and communal property.

Qualitatively organized crime groups are characterized by increasing penetration into the economy, primarily in its core industries, strategically important cost-effective enterprises; an attempt to establish control over the production, supply and sale of certain types of raw materials, goods, services, etc. with the participation of responsible employees of the sphere of economic activity, financiers, managers.

Some of the «criminal authorities» and the leaders of the criminal environment,which had traditionally coordinated and controlled the crimes of a general criminal nature, shifted the emphasis from open criminal criminality to the field of criminal entrepreneurship and economic business.

Organized crime often uses the most severe forms of violence: murder, causing severe bodily harm, illegal deprivation of liberty, etc. Violence, used as a means of combating criminal groups among themselves, is a means of intimidating and physically removing witnesses, journalists, politicians, etc., often with the use of weapons.

As many scientists point out, organized crime groups have the following features: significant quantitative composition (and this is not a simple group of people, but a peculiar hierarchically constructed criminal association), stability, a clear division of responsibilities between their 
members, an orientation towards a common indefinitely long criminal activity, its planning, the division of spheres of influence, the existence of a system of protection against state social control, information and technical security.

Based on the analysis of the typologies outlined in the scientific literature, organized criminal groups can be identified according to several criteria, namely: 1) for criminal-law grounds; 2) by the nature of the participants; 3) by the level of corrupt connections; 4) by the nature of structuring; 5) the territorial prevalence of activities; 6) by the nature of the occurrence; 7) in the presence of a legal cover of activity; 8) in the direction, content and specialization.

According to criminal law, the following types of organized criminal groups can be singled out: 1) an organized group; 2) Pentecost organized group (Part 4 of Article 303 of the Criminal Code of Ukraine); 3) an organized group established in the penal institution for the purpose of terrorizing the convicts or an attack on the administration (Article 392 of the Criminal Code of Ukraine); 4) a gang (Article 257 of the Criminal Code of Ukraine); 5) the law is not foreseen by a paramilitary or armed formation (Article 260 of the Criminal Code of Ukraine); 6) a group whose activity is carried out on the pretext of preaching religious beliefs or performing religious rites and is combined with harm to people's health or sexual mischief (Article 181 of the Criminal Code of Ukraine); 7) a terrorist group or a terrorist organization (Part 4 of Article 258 of the Criminal Code of Ukraine); 8) a criminal organization (Article 255 of the Criminal Code of Ukraine); 9) a transnational organization engaged in violating the law of the order of transplantation of organs or tissues of a person, seizure of a person by coercion or deception of its organs or tissues for the purpose of their transplantation or illicit trafficking in human organs or tissues (Part 5 of Article 143 of the Criminal Code of Ukraine).

By the nature of the participants it seems possible to identify the following types of organized criminal groups: 1) teenage youth; 2) traditional «thieves»; 3) situational and criminal; 4) «new» criminal; 5) the «white man»; 6) mixed.

By the level of corrupt bonds it is possible to allocate the following groups: 1) non-corrupted; 2) low-corrupted groups; 3) medium corrupted; 4) highly corrupted. 
By the nature of structuring, organized crime groups can be classified into: 1) poorly structured; 2) medium-structured; 3) have not been traditionally structured; 4) rigidly traditionally structured; 5) rigid organizationally structured; 6) structured according to the network type.

According to the territorial prevalence organized groups (organizations) can be: 1) local (within the administrative district, the city); 2) regional (on a scale of one area); 3) interregional (on a scale of several areas); 4) national scale (operating within the whole country); 5) international (refers to those related to the criminal structures of other countries).

Depending on the direction, content and specialization of criminal activity, three types of organized community groups are distinguished: 1) groups that specialize in committing common criminal crimes in conjunction with the organization of gambling, extortion, kidnapping, trafficking, etc.; 2) community of economic, commercial, financial orientation, which parasitize on the official structures of society; 3) mixed-type communities that combine the features of the first two organized criminal groups.

Organized criminal groups of economic orientation - this is, as a rule, the unification of specialists and officials of the authorities and management on the basis of common criminal activity. Sociopsychological peculiarities of such groups is that they are created by experienced organizers. Their structure largely formalizes the structure of the organization where it was created. Relations between members of the group often consist in the fact that individual participants do not know the amount of criminal activity in general. Delaying the implementation of cardinal measures to counteract criminal gangs in the economy contributes to their development, creates the preconditions for reproduction, adaptation to new political, socio-economic and other factors, increases the likelihood of communication with state and law enforcement agencies, causes the feeling of impunity in its members, independence and security.

By the nature of the emergence can be identified the following groups: 1) family-clan groups; 2) household allowance; 3) learning environment; 4) sports environment; 5) penitentiary environment; 6) service and labor environment; 7) marginal environment; 8) professional criminals. 
The sign of the legal cover of the activity of criminal groups allows to allocate: 1) criminal groups without legal cover; 2) criminal groups that have a legal cover.

The concept of organized crime is formulated in the current Law of Ukraine «On the Organizational and Legal Foundations of Combating Organized Crime» and includes the totality of crimes committed in connection with the creation and operation of organized criminal gangs. There are about 150 scientific definitions of organized crime, the generalization of which with the formulation of a certain unified concept is quite problematic. Taking into account the listed characteristic criminological signs of organized crime, it can be defined as follows. Organized crime is a unification of the criminal environment for committing crimes on a scale of a particular region, a separate branch of the economy through the formation of stable, united hierarchically constructed criminal groups focused on long-term joint criminal activity in order to receive constant significant income, often with the disguised use of official economic and organizational structures, as well as corrupt elements of the state apparatus.

This definition has a predominantly criminological character and reproduces the directions of counteraction to this crime.

In the orders of the Prosecutor General of Ukraine on the activities of the prosecutor's office for counteraction and prevention of organized crime, it is noted that the prosecutor's offices should pay special attention to complying with the requirements of laws on preventing the occurrence of organized criminal gangs; establishing their corrupt connections with civil servants, officials of the authorities and administration; legalization of proceeds from crime; the use of organized crime in their interests of business entities, organizations, institutions, mass media, public associations, as well as to ensure the proper organization of oversight of observance of laws in the conduct of operational and investigative activities, measures for the timely detection, termination and disclosure of crimes.

The organs of the prosecutor's office in accordance with the requirements of the Constitution of Ukraine, the Laws of Ukraine «On Prosecutor's Office», «On Operational Investigative Activity», «On the Organizational and Legal Foundations of Combating Organized Crime» 
are authorized to oversee the bodies conducting operative-search activity and operational-search prevention.

Compliance with the law in criminal procedure, which is carried out in the form of inquiry, is also subject to prosecutorial supervision. An important component of the criminal procedure of the inquiry agencies, investigators, prosecutors is the identification of the causes and conditions that contributed to the commission of the crime by organized criminal groups (Articles 23, 23-1, 23-2 of the Code of Criminal Procedure of Ukraine).

According to Art. 23-2 of the Code of Criminal Procedure of Ukraine, if it has for the same reasons, makes a separate decision (decree), which draws the attention of state bodies, public organizations or officials to the facts established in the case of violations of the law, the causes and conditions that contributed to the commission of organized crime crimes groups and require action to be taken.

The Criminal Procedure Law empowers the inquiry authority, investigator, prosecutor to establish the causes and conditions that contributed to the commission of the crime, to submit to the relevant state body, public organization or official an application for taking measures to eliminate these causes and conditions.

The study of criminal cases has shown that many of them fail to establish an entire branched system of criminal acts of organized groups and identify their leading core and corrupt connections in higher levels of government. This is due to insufficient attention to these issues during the rapid development of such groups. One of the mistakes at this stage is the lack of a large-scale criminological, economic, financial and economic analysis of the state of the relevant sectors of the economy that became the objects of criminal activity.

Previous work of the governing bodies of these economic objects, as well as control and law enforcement authorities for their inspections, issuance of permits, etc. is not analyzed properly.

Subjects of counteraction to organized crime can be divided into two groups: 1) bodies for which activities to combat organized crime is one of the main functions; 2) bodies that carry out such activities only in the course of performing their basic functions, which are not directly related to the fight against organized crime. 
The first group of subjects includes the Main Department for Combating Organized Crime of the Ministry of Internal Affairs of Ukraine, the Main Department for Combating Corruption and Organized Crime of the Security Service of Ukraine. The Office of the Prosecutor General of Ukraine, as part of the Main Department for the Supervision of Law Enforcement, the Office for the Supervision of the Enforcement of Laws acts by the special units and other state bodies fighting the organized crime and corruption in the conduct of operational-search activities, inquiries and pre-trial investigation.

Consideration of the organizational principles of preventive activities involves: a clear definition of its goals and objectives, methods and methods for their solution; availability of appropriate resources; work planning; coordination of the efforts of the involved actors. Market relations, unlike the economic system that existed in the country with its rigorous control, the mechanisms of distribution from top to bottom, is based on competition, profit making. It is quite natural to shake off the planned principles of state influence on the economy, the mechanisms of regulation of most spheres of life used by the former republics of the USSR. Such a state of affairs could have had no effect on the planning of work on the prevention of crime.

The constant emergence of new forms of socially dangerous activity of organized criminal groups requires an appropriate extension of the system of preventive measures that would reduce the possibility of committing crimes. At the same time, the lack of legal, financial, personnel and other conditions for the implementation of preventive activities requires the search for a variety of ways to increase competence in managing the processes of counteraction to organized crime, making sound and well-considered decisions. That is why the importance of scientifically grounded, highly effective methods of managing the processes of preventing organized crime is increasing.

Prosecutorial supervision provides for the use of the powers given to the prosecutor to stop violations of the law, to take measures to prevent them, to bring to justice the persons who violated the law, restoration of rights and legitimate interests of citizens, etc. For fulfillment of the requirements of Articles 17, 18 of the Law of Ukraine «On the Organizational and Legal Foundations of Combating Organized Crime» by the central apparatus and their subdivisions on the ground of the 
National Bank of Ukraine, the Ministry of Finance of Ukraine, the State Customs Service of Ukraine, the State Control and Revision Service of Ukraine, the State Property The Antimonopoly Committee of Ukraine, the State Border Guard Service of Ukraine, as well as other ministries and departments that have control powers within the bounds of their responsibilities regarding interaction with special units for combating organized crime, supervision is carried out by the branch office of the General Prosecutor's Office of Ukraine.

Public prosecutors must pay particular attention to the effectiveness of the provision of assistance by the said government agencies to special forces; participation in joint events; informing about found illegal actions of legal entities and individuals, testifying to the organized criminal activity or creation of conditions for this, as well as the use of the information received for the timely detection, termination and prevention of such activity. On the basis of the results of mutual verification and verification of the legality of the decisions made on the materials submitted from the supervisory authorities, make the relevant certificates.

To date, it is not everywhere at all and not fully guaranteed that decisive measures are taken to stop the activities of organized criminal groups and to eliminate their economic base by checking compliance with the legislation when corporatization of enterprises that are important for the economy and whose state share is transferred to management of holding and others companies. Rarely, concerted measures are being taken to detect the facts of concealing tax revenue, legalization of proceeds from crime, including using fictitious enterprises, blocking their settlement accounts, canceling state registration, and withdrawing from the shadow circulation of funds and commodities values.

The determining role of the prosecutor's office in counteracting organized crime belongs to the fact that the prosecutor's office is a universal law-enforcement organization. Through its supervision, it checks and assesses the implementation of legislation aimed at combating organized crime in the country, both from the state, first of all law enforcement agencies and non-state actors of prevention and prevention.

In the course of the implementation of the prosecutor's oversight of the enforcement of laws, the prosecutor's offices have the opportunity to expose the facts of corruption in executive and representative bodies of state authority, local self-government bodies, control and law enforcement 
bodies. In the course of so-called supervisory inspections, the prosecutor's office reveals the facts of offenses, which greatly enhances the preventive effect on the negative phenomena being investigated.

The effectiveness of counteraction to crime depends to a large extent on how diverse and complex the approach to solving this problem is, to what extent the joint activity and contact between law enforcement and controlling bodies in combating various manifestations of organized crime are established.

The bodies that carry out state control are the controlling bodies that carry out inter-departmental control. The range of issues that the supervisor has the right to audit is rather narrow, specialized, clearly tied to the tasks facing such an authority. In accordance with the given powers, special control bodies supervise the observance of the mandatory rules in various areas of activity: industry, agriculture, transport, nature protection, etc. Legislative consolidation of the control powers of these bodies provides various normative documents: laws and regulations.

The controlling authorities exercise control in the form of inspections (examination and study of certain areas of financial and economic activity, the results of which constitute a certificate or memorandum); planned and unscheduled audits (documentary control of financial and economic activity, the results of which is an act); Reconnaissance reports, as well as surveys, raids, reviews, etc.

The supervisory authorities should include various state inspections and services, the main task of which is to carry out state control in one or another field of activity. A special feature of the fight against organized crime is the clear interaction between the controlling bodies and the prosecutor's offices in detecting and investigating crimes committed by organized criminal gangs.

Coordination of the work on combating organized crime rests with the Prosecutor General of Ukraine and his subordinate prosecutors.

This control is in the specialized subject of control, as well as in the absence of a departmental interest in its results.

\section{The criminal-law basis for counteraction to organized crime}

The norms that can and should be applied in case of revealing expressions of organized crime are contained both in the General and 
Special Parts of the Criminal Code of Ukraine. With regard to the general foundations of responsibility for any crime, they are always unchanged.

Any crime is committed by a certain subject. In addition, a certain person can act completely independently or in association with someone to varying degrees. On this basis the legislation bases most of the specifics of the responsibility of a particular person for a specific act. Taking into account the development of the rules on complicity as an intentional joint participation of several subjects of the crime in the commission of a willful crime, the legislator indicates that the accomplices of the crime, along with the executor, is the organizer, instigator and accomplice.

This general provision applies to any crime with all possible variations of participation of the indicated accomplices. Part 3 of Article 27 of the Code of Civil Procedure, along with the indication that the organizer is the person who organized the commission of the crime (crimes) or directed its (their) preparation or commission; it is indicated and that the organizer is also a person who formed an organized group or a criminal organization or managed it, or a person who provided financing or organized a concealment of the criminal activities of an organized group or a criminal organization.

Such an instruction should oblige every practice that has encountered in its work with a crime that follows the presence of an organizer for the mandatory establishment of whether he has in this case a case with the manifestation of the activities of an organized group or a criminal organization.

Thus, modern criminal law recognizes the person who committed the crime as having committed one of the following acts:

- organized the commission of a crime (crimes);

- directed its (their) training;

- directed its (their) commission;

- created an organized group or criminal organization;

- performed the function of its head;

- funded its activities;

- organized the concealment of its criminal activity.

Under certain conditions, the particular crime itself must be regarded as committed by a group of persons, a group of persons under a prior conspiracy, an organized group or a criminal organization. 
Although scientists have repeatedly indicated the need for a certain correction of definitions of what crimes are considered to be committed by an organized group or criminal organization, today they constitute the basis for the formation of data on the revealed expressions of organized crime.

Part 3 of Article 28 of the Criminal Code states: «An offense is recognized as committed by an organized group if several persons (three or more) who were previously arranged in a stable association to commit this and other (other) crimes participated in its preparation or commission, united by a single plan with the distribution of functions of the group members aimed at achieving this plan, known to all members of the group»».

That is, the commission of an offense by an organized group is possible in a group of at least three participants (which corresponds to the justification of the occurrence of elements of organization between them), which had previously agreed (the legislator used the term organized) about the commission of at least two crimes (a connection between the two), for this purpose and they shared each of their functions among themselves (obviously the legislator has in mind a role, as it is stated in Article 27 of the Criminal Code of Ukraine, however, to accomplish, to achieve a single, known to all the group members plan, and not predetermined criminal activity in general. At the same time, the legislator points out that such a grouping of the group must be stable, but again it is obvious, at least until the achievement of the same unified plan of crime identified by them.

Given that this norm takes the place of the Criminal Code of Ukraine as one of the bases of counteraction to more and more active organized crime, elements of stability in such an organized group will be understood, the commission of not one, but the system of crimes and awareness of all participants in the commission of these crimes, combined by a unified plan. But it should be noted that the use in criminal law, especially in the Common part of the Criminal Code of Ukraine of such evaluative criminological concepts does not contribute to a real counteraction to organized crime.

In addition, only a small fraction of organized crime will fall under these characteristics, and the requirement for awareness among all group members about the plan of its two or more crimes further complicates the 
issue of their evidentiary confirmation. In addition, it is understood that this is complicity and committed intentional offenses according to the plan, that is, all participants in this group know exactly what they are participating in. For the purpose of self-preservation, the organizationalmanagerial link in the structure of organized crime is far from eager to report on the plans of its activities to all its ordinary members.

However, for today, in order to recognize that a crime was committed by an organized group, it is necessary to establish all of its features.

If, conversely, draw attention to the indication in the norm of the law that an organized group is a group of individuals that are united by a single plan with the distribution of functions, and execute them in order to achieve this plan, known to all members of the group, it is quite logical to assume that this means the commission of one crime, though thought-out, continued, and not at least two. At that time, the application of the norm of committing a crime in complicity with the division of roles would be simpler and could be applied to a greater number of crimes, which are manifestations of both the activities of organized crime, and not only it. Such a norm could be considered more in part as a more socially dangerous form of complicity in comparison with the commission of a crime by a group of individuals on the basis of a preliminary conspiracy on a particular one identified crime. It is the specificity of organized crime in concealing a significant number of their crimes, which in many cases does not allow at least two at the very least.

In addition, according to Art. 67 of the Criminal Code of Ukraine one of the circumstances, which imposes a penal code, recognizes the commission of a crime only as a «group of persons under a previous conspiracy (part two or three of Article 28)». The legislator for some reason under the group of persons under the previous agreement proposes to consider and Article 3, Article 28 - the commission of an offense by an organized group, in accordance with all the description envisaged by it. A certain «pull-up» in this case, one form of complicity under the other does not contribute to their clear and effective application. However, in imposing a sentence, the court can not recognize as imposing penalties circumstances not specified in part one of Article 67 of the Criminal Code of Ukraine.

In many articles of the Special Part, as an qualifying or especially qualifying attribute, an indication of its commission by an organized 
group is used. However, on the one hand, in most cases, the legislator uses it to express the particular danger of committing this crime precisely in the manifestation of organized crime through the criminal activities of the most organized group or organized group as a structural part of the criminal organization (smuggling, seizure of hostages, illegal deprivation of liberty, trafficking in persons, robbery, extortion, legalization of proceeds from crime, etc.). But on the other hand, such an indication is not contained in all articles of the Special Part of the Criminal Code of Ukraine, which may relate to the manifestations of Ukrainian organized crime.

In the General Part of the Criminal Code, the legislator almost always speaks of an organized group or criminal organization inseparably and in terms of understanding who is the organizer and what should be their responsibility.

Part 4 of Article 28 of the Criminal Code of Ukraine is an indication of a criminal organization, the place of which in complicity is also considered as conditioned by the need for more active counteraction to manifestations of organized crime. In particular, it is noted that «a crime is recognized as a committed criminal organization if it is committed by a stable hierarchical association of several persons (five and more), whose members or structural units were organized by prior conspiracy for joint activities for the purpose of directly committing grave or especially grave crimes committed by the members of this organization, or the management or coordination of the criminal activities of other persons, or the provision of the functioning of both the criminal organization itself and other criminal groups».

Drawing attention to the definition of what crime should be considered committed by a criminal organization, it is immediately apparent that the legislator no longer uses the phrase «group of persons» or «several», but points to the unification of several persons at once, raising their number to $\mathrm{n}$ ' even more. Such an association should not only be sustainable, but also hierarchical and may have separate structural elements, which should also be pre-merged. Members of the association or its structural units must pre-arrange joint activities, the purpose of which must be: A) the direct commission of grave or especially grave crimes by the members of this organization; B) management or 
coordination of criminal activities of other persons; C) ensuring the functioning of both the criminal organization and other criminal groups.

This definition contains many valuables, such as those dictated by international norms, which somewhat affect the speed, practicality and effectiveness of further prosecution of the members of such a criminal organization. There are no indications of committing an offense by a criminal organization in any of the articles of the Special Part of the Criminal Code of Ukraine as a qualifying or particularly qualifying attribute, as it is inherent in other forms of complicity, in particular regarding the commission of an offense by an organized group.

The legislator used the approach that provided for responsibility for the creation, participation in such a criminal organization, etc., as a separate crime in the field of crimes against public safety.

In accordance with the rules concerning the criminal liability of accomplices enshrined in Art. 29 of the Criminal Code of Ukraine the actions of the principle of individualization of punishment, in the case when the crime is committed with the distribution of roles, the situation is as follows. The organizer, the instigator and the accomplice are subject to criminal liability under the relevant part of Article 27 and the article (part of the article) of the Special Part of the Criminal Code of Ukraine, which provides for an offender committed by the executor. Contributors are not subject to criminal liability for acts committed by the executor if it was not covered by their intent.

Signs describing the identity of an individual accomplice of a crime are to blame only for this accomplice. Other circumstances aggravating the responsibility and stipulated in articles of the Special Part of the Criminal Code of Ukraine as signs of a crime affecting the qualification of the actions of the executor, shall be blamed only for the accomplice who was aware of these circumstances.

However, the issue of criminal liability of organizers and participants of an organized group or criminal organization was passed by the legislator in a separate article (Article 30 of the Criminal Code of Ukraine), which provides for the following. The organizer, as an organized group and a criminal organization, is liable to criminal liability for all crimes committed by an organized group or criminal organization, if they were covered by his intent. 
Other members of an organized group or criminal organization are held criminally liable for crimes committed or committed by them, regardless of the role they committed in the crime of each of them. In fact, the greater burden of liability lies with the organizers, and with regard to the rest of the participants, they are responsible for the crimes they were involved in preparing or committing, regardless of the role they played.

Taking into account such a leveling in the General Part of the CCU of the fundamentals of the responsibility of the organizer of the organized group and the organizer of the criminal organization, it would be advisable to indicate in the $\mathrm{CCU}$ the responsibility not only for the creation of a criminal organization, but also for the creation of an organized group, its management or its financing, or concealment of its activities.

Regarding the separate responsibility for the creation of an organized group, the law provides Article 181 of the Criminal Code «Attack on the health of people under the pretext of preaching religious beliefs or performing religious rites», which provides for responsibility for such acts as «the organization or leadership of a group whose activities are carried out under the pretext preaching religious beliefs or performing religious rites, and combined with causing harm to people's health or sexual harassment and Article 392 «Acts that disrupt the work of penitentiary institutions», that is, «terrorist activities in penitentiary institutions or an attack on the administration, as well as the organization of an organized group for this purpose or active participation in such a group committed by persons serving sentence imprisonment or in the form of restraint of liberty». The aforementioned provisions also point to the understanding of organized groups by the legislator as a possible form of manifestation of organized crime.

As an explicit basis for bringing to criminal responsibility representatives of organized crime, in the active part of the Criminal Code of Ukraine in the Special Section, among crimes against public safety, it is precisely Article 255, entitled «Creation of a criminal organization», namely: "Creation of a criminal organization for the purpose of committing a serious or especially grave crime as well as the management of such an organization or participation in it, or participation in crimes committed by such an organization, as well as the organization, management or facilitation of a meeting (gathering) of representatives of 
criminal organizations or organized groups to develop plans and conditions for the joint commission of crimes, material provision of criminal activity, or coordination of activities of associations of criminal organizations or organized groups - shall be punishable by imprisonment for a term of five to twelve years»».

Of course, its provisions are too voluminous, there are many acts that do not contribute to its application, it should be divided into two separate articles or at least structured within one, but for today, the responsibility in this article is for the following groups of acts:

A) regarding the creation and criminal activity of a criminal organization:

- the creation of a criminal organization for the purpose of committing a grave or particularly serious crime;

- management of such an organization;

- participation in it;

- participation in crimes committed by such an organization.

B) for a meeting of representatives of criminal organizations or organized groups for a certain purpose, ie for:

- organization of the meeting;

- meeting management;

- facilitating the meeting.

The purpose of such a meeting of representatives of criminal organizations or organized groups may be:

- the development of plans and conditions for the joint commission of crimes;

- material provision of criminal activity of criminal organizations or organized groups;

- coordination of activities of associations of criminal organizations or organized groups.

That is, it is not only the responsibility of the organizer for the creation of a criminal organization, the article also contains an indication of elements essential to the fight against organized crime, such as participation in a criminal organization and participation in the crimes committed by it. Such an instruction distinguishes their responsibility from the other accomplices who will comply with the general rules of complicity. 
In fact, today, this means that Article 255 of the Criminal Code should apply in all cases where the commission of a crime is a criminal organization or simply the discovery of the participant of a criminal organization - for participation in a criminal organization or participation in its crimes. However, in practice, this does not happen, which, accordingly, makes it impossible to obtain more or less reliable data on the activities of criminal organizations in Ukraine.

In addition, according to Part 2 of Art. 255 of the Criminal Code of Ukraine a person other than the organizer or the head of a criminal organization shall be released from criminal liability for the commission of an offense established by part one of this article if he has voluntarily declared a criminal organization or participated in it and actively contributed to its disclosure.

And according to Part 2. Art. 31 of the Criminal Code of Ukraine «Voluntary refusal of partners», are not subject to criminal liability in the event of a voluntary refusal by the organizer, instigator or accomplice, if they have turned away the commission of the crime or timely informed the relevant authorities about the crime that is being prepared or committed. That is, the organizer of the organized group does not have a separate responsibility for the creation of an organized group, it is not provided as a separate crime in the Special Part of the Criminal Code of Ukraine. In addition, the organizer is not subject to criminal liability and with the specified voluntary refusal, as well as the instigator and accomplice - members of the organized group.

As already noted among the articles of the Special Part of the Criminal Code there is no indication of the possibility of committing a crime as a criminal organization or a qualifying qualification. The only case of a similar mention is Article 143 «Violation of the lawful procedure for the transplantation of organs or tissues of man», where Part 5 provides for responsibility for «participation in transnational organizations engaged in such activities.» However, this refers to «transnational organizations», and not «transnational criminal organizations», which is precisely what the legislator means in this case, is not explicitly indicated.

Article 257 «Banditism» - «the organization of an armed gang for the purpose of attacking enterprises, institutions, organizations or individuals, as well as participation in such a gang or in the attack that they are 
carrying.» Here obviously follows the analogy of building the norm as well as the creation of a criminal organization. In this case, the legislator, to a certain extent, distinguishes not the «creation», but the «organization» of the gang, participation in it and the participation in the crimes committed by it.

The meaning of «gang» is not disclosed in the code, and this concept is actually applied to both an armed organized group and an armed criminal organization, but it is worth noting that there are no special features of a gang, except for weapons, which the code itself does not contain.

Obviously, in order to comply with a certain unified approach to such definitions, and clarifying their essence, it would be worthwhile to record under banditry - «the creation of an armed organized group (criminal organization), participation in it ... in order ...».

Article 258-3 «Creation of a terrorist group or a terrorist organization» has also been formed, where the legislator already, for the first time, equates the responsibility for the creation of both «group» and «organization», and secondly, again does not reveal their essence. It is clear that these norms appeared in the Criminal Code of Ukraine as the fulfillment of the requirements of international obligations undertaken by Ukraine, however, taking into account the terminology of the Criminal Code of Ukraine, it would be more appropriate to indicate «Creation of an organized group or a criminal organization for the purpose of committing a terrorist act ...».

Also, Article 260 of the Criminal Code applies to «Creation of nonlaw-based paramilitary or armed formations» in a note which contains their understanding, nevertheless, the legislator uses one more new term «formations».

In addition, we can not but point out that the legislator uses the term «commissioned» to commit an offense, which may also apply to manifestations of organized crime. This applies to two acts such as intentional murder (Part 2, Article 115) and intentional grave bodily harm (Part 2, Article 121). To attribute such crimes to the manifestation of organized crime again it is necessary to establish separately the creation of a criminal organization, with all its features (five and more persons, stability, hierarchy, etc.), and to associate it with crimes committed to order. 
Such procedural complexity with the application of criminal law aimed at counteracting organized crime leads to the fact that a large number of acts that clearly trace the activities of organized crime do not receive appropriate and proper qualifications remain unopened or closed for reasons of lack of evidence, and therefore, their representatives do not carry the full penalty of their actions, and the detected acts do not receive their respective reflection in the official statistical reporting. As a result, science criminology can not give a real, supported by figures criminological analysis of organized crime. Thus, the situation is formed where organized crime is manifested everywhere and actively discussed, however, according to official data, its activity is rather low.

Only according to the statistics for 2014, under Article 255 of the Code of Criminal Procedure «Establishment of a criminal organization» only 2 proceedings are recorded. But about «Assistance to members of criminal organizations and the hiding of their criminal activity»-art. 256 $\mathrm{KKU}$, registered 42 proceedings.

It is unlikely that the participants of the two listed criminal organizations are assisting the parties, and such proceedings are not united. Banditry (Article 257 of the Criminal Code) - 11 proceedings; the creation of paranoid or armed formations not provided by law (Article 260 of the Code of Civil Procedure) - 414 proceedings. Only under Article 258-3 of the Criminal Code "Creation of a terrorist group or terrorist organization», 427 procedures were registered with the security agencies, 48 of them were terrorist financing (article 258-5 of the Code of Civil Procedure), smuggling of narcotic drugs, psychotropic substances, their analogues or precursors or counterfeit medicines means (Article 305 of the Criminal Code of Ukraine) - 150 procedures; illegal transfer of persons across the state border of Ukraine, (Article 332 of the Code of Civil Procedure) - 157 proceedings, etc.

From the above it is seen the probability that today law enforcement agencies are not actively using Art. 255 of the Criminal Code of Ukraine, or in all other cases (except for two recorded in accordance with this article), crimes committed by organized groups, terrorist groups or other complicity or alone.

Proceeding from the content of modern criminal law, manifestations of organized crime are more socially dangerous. In fact, it acts both through organized groups and through criminal organizations. The basis 
of the criminal liability of their organizers and participants is quite different.

Article 255 of the Code of Criminal Procedure should be more actively applied by law enforcement agencies, in all cases when it is manifested as a criminal offense by a criminal organization or in the case of the very discovery of a participant in a criminal organization for participating in a criminal organization. In order to simplify the procedure for its use it is necessary to review the definitions of not only a criminal organization, but also an organized group, referred to in Art. $28 \mathrm{CCU}$ in the direction of delimiting their criminological features from the subjective and structural and systemic basis of activity. Responsibility for creating and participating in an organized group should also be appropriate.

\section{CONCLUSIONS}

Organized crime contravenes existing social relations, causes or is capable of causing damage to the rights and interests of citizens, communities, the state and society as a whole, impedes the gradual development of the state.

The growth of crime occurs on the background of a rapid increase in its organization. This leads to mass creation and functioning in Ukraine of various types in its orientation, structure, scale of influence of criminal formations, which sometimes form integral systems that carry out continuous criminal activity, the main purpose of which is the illegal gaining of profits and profits.

Such activities are usually combined with providing criminals with special protection (invulnerability) from social control and legal influence on them through the use of such means as violence, torture, intimidation, blackmail, discredit, corruption, as well as penetration of the representatives of the criminal environment in official state and public (economic, power, administrative, law-enforcement) structures, investing in them significant, money-laundered money to bribe officials.

Therefore, crime, including organized crime, is well founded today as a real threat to the national security of the state, due to the comprehensive nature of its impact on various spheres of public life. The effectiveness of the national security strategy depends on conducting systemic internal 
reforms that should be aimed at creating a flexible, capable and democratic system of public administration.

Part of such activity of the state should be constant monitoring of legislation aimed at counteraction to organized crime, its current challenges, clarity and unambiguous application. Therefore, in order to more effectively counteract organized crime through the action of criminal law, their terminology should be united with reflection of the essential details and clear to the understanding and application.

\section{SUMMARY}

The article is devoted to the study of the legislative, in particular, the criminal-law basis for counteraction to organized crime in Ukraine. Organized crime is currently regarded as a real threat to national security in connection with the inclusive nature of its impact on various spheres of public life. Attracting representatives of organized crime to criminal responsibility for acts recognized as a crime is a clear requirement of the present. In order to successfully fight organized crime, joint efforts are needed to counteract criminal gangs across the European space, joint mobilization of law enforcement and judicial authorities, balanced implementation of measures and an integrated strategy that sets priorities and clear goals for the implementation of relevant action plans. It is specified that the part of such activity of the state should be constant monitoring of legislation aimed at counteraction to organized crime, its current challenges, clarity and unambiguous application. Therefore, in order to more effectively counteract organized crime through the action of criminal law, their terminology should be united with reflection of the essential details and clear to the understanding and application.

\section{REFERENCES}

1. Кримінологія: Загальна та Особлива чистини: підруч. для студентів юрид. спец. вищ. навч. закладів / [Даньшин I.M., Голіна В.В., Кальман О.Г., Лисодєд О.В.]; за ред проф. I.M. Даньшина. - X.: Право, 2003. - С. 220.

2. Кримінальний кодекс України: чинне законодавство зі змінами та доповненнями станом на 8 лют. 2013 року: (ОФІЦ. TEKCT). - К.: ПАЛИВОДА А.В., 2013. - 216 с. 
3. Жаровська Г.П. Співучасть у злочині за кримінальним правом України: автореф. дис... канд. юрид. наук: 12.00 .08 / Г. П. Жаровська / НАН України, Інститут держави і права ім. В.М.Корецького. - К., 2004. - 19 с.

4. Українець В.В. Кримінальна відповідальність за створення злочинної організації: автореф. дис... канд. юрид. наук: 12.00 .08 / В.В. Українець / Акад. адвокатури України. - К., 2009. - 20 с.

5. Кваша О. О. Співучасть у злочині: сутність, структура та відповідальність [Текст] : автореф. дис. ... д-ра юрид. наук : 12.00 .08 / Кваша Оксана Олександрівна ; Нац. акад. наук України, Ін-т держави і права ім. В. М. Корецького. - К., 2013. - 36 с.

6. Митрофанов І. І., Притула А. М.Співучасть у злочині: навч. посіб. / І. І. Митрофанов, А. М. Притула. - О.: Фенікс, 2012. - 205 с.

7. Єдиний звіт про кримінальні правопорушення по державі за січень-грудень 2014 року. [Електронний ресурс]. - Режим доступу: http: http://www.gp.gov.ua/ua/stat.html

\section{Information about the author: Miniailo N. Y.}

Candidate of Juridical Sciences, Associate Professor at the Department of Special-Legal Disciplines of the V. I. Vernadsky Taurida National University 33, Ivana Kudri str., Kyiv, 01042, Ukraine 